Vol 41 (2016) No 184 363-382

\title{
Classifying Universities in Turkey by Hierarchical Cluster Analysis
}

\author{
Nihat Erdoğmuş ${ }^{1}$, Murat Esen ${ }^{2}$
}

\begin{abstract}
Classifying universities is regarded as an efficient strategy for developing institution-based policy for different types of universities. In Turkey, there is no widely accepted classification or official classification of universities for researchers and policy makers. Regarding this need, the first purpose of this study is to classify universities in Turkey on the basis of institutional size and performance. Since the focus of the study is institutional size and performance, researchers approach the subject from the perspectives of management and organization. Universities were classified using hierarchical cluster analysis. All state and foundation universities were included in the study. The data sources were statistics of the Council of Higher Education (CoHE), ranking lists, University Ranking by Academic Performance (URAP), Ranking of the Entrepreneurial and Innovative University Index (TUBITAK), strategic plans and annual reports of higher education institutions, and related data on research and publications. Universities were clustured on the basis of objective data not predetermined criteria. The main variables for cluster analysis were quantitative measures, ranking scores, and measures of the quality of teaching and research for each university. The results of the cluster analysis showed that clustering universities by institutional size and performance as two separate variables provided better results. The scale and tenure of universities differentiated them in terms of institutional size and performance variables. Universities founded in the same years were divided into two clusters, mainly according to the size of their vocational schools. It was also found that when publication performance was expressed, those universities that were small/medium sized, focused, and long tenured were separate from other universities.
\end{abstract}

DOI: 10.15390/EB.2016.6232

\footnotetext{
${ }^{1}$ Ylldız Technical University, Faculty of Economics and Administrative Sciences, Department of Business Administration, Turkey, nihaterd@yildiz.edu.tr

2 İzmir Katip Çelebi University, Faculty of Economics and Administrative Sciences, Department of Business Administration, Turkey, muratesentr@gmail.com
} 


\section{Introduction}

Performance measurement in higher education has become an important subject in recent years. Drivers of performance measurement for universities are competition for limited resources in fundraising and the need to develop effective universities (Ibáñez, Larrañaga, \& Bielza, 2013). The objective, reliable, and accurate measurement of institutional performance may help with allocating funds efficiently, prioritizing research and educational investments, informing the public and stakeholders, attracting candidate students and researchers, and internal self-evaluation and improvement (Ioannidis et al., 2007). Policy makers regard measuring performance as a first step for ensuring university resources are properly allocated (Raponi, Martella, \& Maruotti, 2016). Clustering and ranking are both instruments for measuring performance in universities (McCormick, 2008).

Classifying universities is regarded as an efficient strategy for policy development in the field of higher education (Shin, 2009) since classification provides a basis for diversified policy approaches and collaboration between institutions, methodological and analytical tools for research, and transparency for stakeholders and other organizations (Bartelse \& Vught, 2007). Initially, universities were classified in terms of law (legal classification), and similarities and differences (the Carnegie classification); however, recent classification studies focused have on performance, especially research performance. Researchers and policymakers have used a variety of criteria to develop typologies for higher education institutions (Shin, 2009). The value of a classification is closely linked to its intended use rather than an absolute standard for the best classification (McCormick \& Zhao, 2005). In order to build a useful classification system, we must consider multiple factors, such as the purpose of the classification, the nature of the objects or cases to be classified, the criteria and data available for classification, and the degree of differentiation (McCormick \& Zhao, 2005).

Global ranking lists have attracted much media and public attention since 2000. Rankings provide easily interpretable information about universities, stimulate competition among them, help to differentiate universities, and serve as a framework for quality assessment (Harvey, 2008). Ranking systems have an impact on universities and their stakeholders (Thakur, 2007). Governments use rankings for the allocation of funds and quality assessment. Employers use rankings to select new graduates. Students seeking to enter institutions with a high reputation use rankings in their decision making. However, rankings are also criticized for the selection of indicators that make up the index. The main criticisms are that the ranking systems use measurable data rather than important and relevant qualitative ones (Stella \& Woodhouse, 2007), apply different calculation formulas (Ioannidis et al., 2007), do not reward teaching (Van Dyke, 2005), and ignore the diversity of institutions (Carey, 2006). According to Raponi et al. (2016), purely descriptive approaches may fail to capture the complex structure of universities. The best way to compare faculties and universities is by focusing on particular research fields and using clustering techniques rather than straight ranking.

Researchers and policy makers are interested in classifying universities on the basis of the whole institution. Bartelse and Vught (2007) identified the components of a typology as education, research and innovation, student and staff profiles, and institutional variables in a European project. In Australia, five dimensions were used: teaching and learning, student profile, research involvement, knowledge exchange, and international orientation. The Australian Department of Education, Training and Youth Affairs (DETYA) (1998) classified Australian universities using cluster analysis according to six criteria: size, overseas orientation, diversity, internal/full-time orientation, financial research orientation, and staff research orientation (Valadkhani \& Worthington, 2006). The South Korean government has initiated a classification of universities at least three times since the mid-1990s. However, the impacts of these initiatives are relatively limited because they are not widely accepted as classification schemes. A lack of a classification scheme for universities increases limitations in academic research and policy development (Shin, 2009). 
Initially, most analyses focused on the institutional-level classification of universities, and the focus later shifted to research performance and disciplines (Valadkhani \& Ville, 2009). Since universities often have particular strengths in one field and weaknesses in others, whole-institution analysis is problematic. The decision to consider research performance as a classification criterion was based on two reasons: (1) availability of the data and (2) research outputs that are relatively easier to quantify and qualify (Chu $\mathrm{Ng} \& \mathrm{Li}, 2000$ ). Typical research performance indicators include the number of publications, number of citations of publications, journal impact factors, and reputational rankings. For example, Ibáñezet al.'s (2013) study focused on research activity used productivity, visibility, quality, prestige, and internationalization as the performance indicators. It is argued that for better construct validity, the total number of citations should be preferred over the total number of papers in research performance studies (Ioannidis et al., 2007).

\section{Higher Education System in Turkey}

The administration of higher education was centrally restructured in accordance with the new Higher Education Law (No. 2547). All higher education institutions were designed as universities under the supervision of the Council of Higher Education (CoHE) (Yuikseköğretim Kurulu). The CoHE supervises the higher education system as an autonomous institution. It is responsible for the planning, coordination, and governance of the higher education system in Turkey. Turkish universities offer associate, bachelor, graduate, and post-graduate degree programs (YÖK, 2015). In Turkey, academic staff are classified as either faculty members with a Ph.D. (professors, associate professors, and assistant professors), teaching staff (lecturers, instructors), research assistants, or support staff (specialists, translators, education planners). In addition to state universities, non-profit foundation universities have been established since 1984. There is a binary system consisting of the state and non-profit foundation universities in higher education. The operating revenue of state universities comes from the government. The funding of foundation universities comes from a number of sources: the founder, tuition fees, and other income. The percentage of state universities in higher education is still high, and they are largely funded by central administration (Tosun, 2015). The government funds state universities without any specific assessment of performance. It seems that funding is more related to institutional size than to performance.

Turkish higher education has expanded remarkably over the last 30 years, and this expansion has been particularly rapid since 2006 (Özoğlu, Gür, \& Gümüş, 2016). With an increasing young population and demand for higher education, the Turkish government has sought to increase the number and capacity of higher education institutions. The number of universities increased from 27 in 1982 to 192 in 2015. Most of these universities were established in the last ten years. At the begining of the 1980s, there were 4,905 academic staff members with a Ph.D. out of a total academic staff of 20,917. The number of academic staff members with a Ph.D. increased to 70,419 out of a total of 150,575 academic staff in 2015. The number of students enrolled in higher education in Turkey rose from 281,538 in 1982 to 6,062,882 in 2014-2015 (istatistic.yok.gov.tr). Like many countries, Turkey faces the need for more effective higher education. It is clear that existing resources should be used to meet the increasing demand for research, education, and services. Unfortunately, there has been very little quantitative work that provides guidance on the ongoing strategies and policy changes in Turkish higher education.

\section{Efforts to Improve Institutional Performance}

The literature on Turkish higher education includes field-based reports and publications, as well as some research. Among the field reports and publications, the following ones should be mentioned. The Council of Turkish Higher Education prepared periodic publications on recent developments in the Turkish higher education system (see YÖK, 2015b for details), such as Turkish Higher Education Strategy (2007) and Growth, Quality, Internationalization: A Roadmap for Turkish Higher Education (2014). These documents and publications describe the current situation and problems of the Turkish higher education system with statistics and suggested strategies and policies for higher education. In addition to these documents, we should also mention the works on the Bologna Process (2010) and International Higher Education Congress (2011), as well as reports on specific 
disciplines such as medicine education and manpower in health (2013), vocational and technical education $(2002,2007)$, teachers and education (2007), and law (2000). These documents focus on the disciplines, similarly describing the field with statistics, and suggest strategies and policies. In addition to these documents that were prepared with the support or supervision of the CoHE, there are "restructuring of higher education" reports prepared by organizations independent of the CoHE.

Regarding performance measurement in Turkish higher education, we should refer to the Bologna Process, YÖDEK, strategic plans, and yearly institutional evaluation reports. The CoHE, as the national authority of the Bologna Process, has carried out various projects of the National Teams of Bologna Experts financed by the European Commission and coordinated by the CoHE since 2004. The CoHE tried to integrate all higher education institutions in Turkey to the European Higher Education Area. In order to evaluate and develop the quality of education, including teaching and research activities, with regard to the Standards and Principles of European Quality Assurance, the CoHE published the guideline "The Regulation of Academic Evaluation and Quality Development in Higher Education Institutions" (2005). The commission of Higher Education Academic Evaluation and Quality Development began yearly evaluations of higher education institutions, but the work has not been sustained. Higher education institutions obligatorily prepare strategic plans under Law 5018, but this is not very effective. In 2014, the CoHE aimed to coordinate and integrate yearly reports submitted to the CoHE and the government. The CoHE announced an institutional evaluation of higher education institutions report in UAK in June 2014. The first institutional evaluation report focused on the size and capacity of higher education institutions because of the available data. The aim of the report was to evaluate higher education institutions in terms of their research, education, services, and governance.

The works described above, the Bologna Process, the guideline on academic evaluation and quality development, and yearly institutional evaluation reports have not continued, but the preparation of strategic plans remains an obligation. In this context, the Council of Higher Education Qualifications, Quality Assurance and Accreditation Commission (YÖKAK) was constructed in May 2014. It was declared that the council "will provide coordination about all topics under the title of quality considering the administrative and functional activities within the Council of Higher Education and function so as to transform the national and international developments in regard to the renovation of higher education into policy measures and action title that can shape the implementation" (YÖK, 2015a, http://www.yok.gov.tr/web/uluslararasi-iliskiler/kalite-guvencesi). These works can be regarded as initial studies to evaluate higher education institutions in Turkey. The main difficulties for these works are their sustainability, their dependence on people, and the availability of systematic data. It can be argued that ongoing works and changes in the higher education field require reliable and valid data on higher education institutes and the higher education system in Turkey.

As mentioned earlier, there are a few studies on the higher education system in Turkey. Küçükcan and Gür (2009) conducted a comparative investigation of management systems in higher education. Günay and Günay (2011) studied quantitative developments in higher education in Turkey. Tosun (2015) analyzed the current situation of state universities, using data from 2010 and 2013, in terms of six dimensions: education revenue, education structure, education quality, publications, projects, and entrepreneurship-innovation. Üsdiken, Topaler, and Koçak (2013) examined the effects of state intervention on diversity in university types in the Turkish higher education field. They found that regime change (YÖK) altered the structure of the field. They conducted cluster analyses using four variables: a) faculty combination, b) specialty in occupations and education levels, c) the share of vocational schools, and d) medium of instruction. The results showed that university types are a recombination of old and newly imposed requirements. The authors concluded that the results were shaped by legal imposition and the history of the field more than by competitive processes. 
The lack of a classification schema for universities in Turkey brings limitations in academic research as well as policy development. Without a classification schema for Turkish universities, researchers and policy makers have to work with a relatively arbitrary selection of comparable groups. This type of work might lead to inappropriate and inconsistent conclusions. Regarding this need, the first aim of this study is to explore the variables for classifying higher education institutions in Turkey on the basis of institutional size and performance. The second aim is to classify universities using a cluster methodology. Since the focus of the study is institutional performance, researchers approached the subject from the perspectives of management and organization.

In this study, five research questions are addressed:

1. What are the variables that can be used to classify universities in Turkey?

2. How can universities be classified in terms of quantitative variables?

3. How can universities be classified in terms of ranking scores?

4. How can universities be classified in terms of teaching and research performance?

5. What are the similarities and differences between quantitative, ranking, and performancebased clusters?

The paper is organized as follows. The next section provides a description of the data used in the analysis and clustering methodology. Then, the findings of clustering are presented and discussed. The paper ends with some concluding remarks and policy recommendations in the final section.

\section{Method}

\section{Data Collection}

The main objective of this study is to clasify universities in Turkey in terms of their institutional size and performance. Before the cluster analysis, we needed reliable datasets. The datasets were built as follows. In the first step, taking the existing literature into account, we developed a framework for the classification of universities. The framework consists of quantitative variables related to universities, ranking scores, and the quality of teaching and research for each university. In the second step, we collected data from the statistics of the CoHE (YÖK), Web of Science, University Ranking by Academic Performance (URAP), Ranking of the Entrepreneurial and Innovative University Index (TUBITAK), Ranking Web of Universities (Webometrics), and strategic plans and annual reports of higher education institutions, as well as data on research publications and other related information. During the data collection process, we could not find data for some variables such as finances and research funds. In the end, we decided to build datasets consisting of available and reliable data. The datasets can be classified as data on the quantitative size of universities, data on rankings, and data on performance.

The first dataset, which we call the quantitative dataset, includes the statistics of 104 public and 69 foundation universities. The statistics consist of legal status, foundation year, size of the student body, size of the staff, number of programs offered, number of articles in the Web of Science, number of academic units, and, if available, budgets for each university. In addition to the statistics of the CoHE, we examined universities' strategic plans and annual reports to collect institutional data. The second dataset, what we call the rankings dataset, includes 82 universities in the URAP (2015), 50 universities in the Ranking of the TUBITAK (2015), and 176 universities in Webometrics. Only universities that are in the ranking lists are included in this second dataset. The third dataset, which we call the performance dataset, was produced from the statistics of the first dataset. It contains performance measures for publications in journals indexed by SCI, SCI Expanded, SSCI, or AHCI per academic staff member with a Ph.D., and the number of students per academic staff member with a Ph.D. for all public and foundation universities. 


\section{Cluster Analysis}

The data were classified using hierarchical cluster analysis. Cluster analysis is a multivariate statistical technique that is used to classify cases according to the similarity or dissimilarity of their characteristics. Hierarchical cluster analysis tries to minimize within-group variance while also maximizing between-group variance (Hair, Anderson, Tatham, \& Black, 1998, p. 470). We used Ward's (1963) algorithm. In this study, we classified universities on the basis of objective data instead of predetermined criteria as we preferred a data-driven approach. All state and foundation universities were included in each cluster analysis if they were in the related datasets.

In the first cluster analysis, as we expected, we found that using all three main variables (quantitative, ranking, and performance) did not produce meaningful clusters. This analysis showed that we should conduct a separate cluster analysis for each variable (quantitative, ranking, and performance). We also recognized that we should divide each dataset into data on state and foundation universities and then conduct a cluster analysis separately for the two types of universities. On the basis of the findings of a trial cluster analysis, we decided on a three-step cluster analysis for the state and foundation universities. The steps were as follows:

- Cluster analysis of universities on the basis of quantitative measures

- Cluster analysis of universities on the basis of ranking measures

- Cluster analysis of universities on the basis of performance measures

Using the datasets and the findings of a pilot cluster analysis, we developed a framework for cluster analysis. The main variables and sub-variables for classification are the following:

- Quantitative variables

$\circ$ foundation year

- number of academic units

○ number of students

- number of academic staff

- number of academic programs offered

- Ranking scores

- URAP) score

- Ranking of the TUBITAK score

- Webometrics score

- Performance variables

- Research quality: Publications per academic staff member with a Ph.D.

- Teaching quality: Students per academic staff member with a Ph.D. 


\section{Findings}

\section{Descriptive Statistics}

Findings on Variables for Clustering Universities

One of the main findings of this study is that state and foundation universities should be included in separate cluster analyses because of the scale and tenure differences between the two types of universities. Therefore, we conducted a cluster analysis separately for the two types of universities in this study.

It was found that quantitative indicators are appropriate criteria for clustering universities in Turkey in terms of institutional variables. These criteria are the following:

- Foundation year

- Number of vocational students

- Number of undergraduate students

- Number of graduate programs

- Number of vocational school programs

- Number of undergarduate programs Number of master programs

- Number of Ph.D. programs

- Number of faculty members

- Number of departments

- Number of all academic programs

In addition, the following three ranking scores were found to be appropriate for the classification of universities in terms of research and innovation performance.

- URAP score

- Ranking of the TUBİTAK score

- Webometrics score

These three rankings include a limited number of universities: TUBITAK (50), URAP (86), and Webometrics (132). The analysis is based on entire institutions. Since these three ranking scores were used together in the cluster analysis, the lowest number of cases was used, which means the results of the cluster analysis are based on 50 universities. We believe that if the number of cases (universities) included in the rankings is increased, the rankings could be used for clustering the research performance of the universities. In addition to these rankings, it is necessary to elaborate the analysis from the level of whole institutions to that of specific fields, as whole-institution analysis is problematic in that universities may have particular strengths in one field and weaknesses in others.

Since the three rankings mentioned above used a limited number of universities, not all the universities were included in the cluster analysis that was based on the rankings. In order to include all the universities for clustering in terms of academic performance, we conducted another cluster analysis using research and teaching quality. The performance indicator for research quality is the number of publications per staff member with Ph.D, and for teaching quality, it is the student/staff ratio. For these performance indicators, there are still limitations. For example, new universities have lower student/staff ratios. Therefore, researchers and policy makers should be careful while interpreting the results.

Although there are some criticisms of the methodologies used in ranking systems, ranking systems still shape the behavior of universities (OECD, 2006). Ranking results are increasingly being used as performance indicators to evaluate and monitor processes. Given this influence, universities are developing organizational policies and strategies in order to optimize their position in ranking systems (Marginson \& Van der Wende, 2007). 
Lastly, regarding the performance variables of universities, it can be argued that for teaching quality and the number of students per academic staff member with a Ph.D. and, for research quality, the number of publications per academic staff member with a Ph.D. are better variables for the cluster analysis. The availability of data on research incomes is one of the main limitations in clustering universities in terms of performance.

\section{Results of Cluster Analysis by Institutional Size}

This section presents the results of cluster analyses on the basis of quantitative variables. The results of state and foundation universities are given in Tables 1 and 2 .

Table 1. Hierarchical Cluster Analysis of State Universities According to Quantitative Variables

\begin{tabular}{|c|c|c|c|c|c|c|}
\hline Cluster & $\mathbf{n}$ & Universities & Variables & Mean & Min. & Max. \\
\hline Cluster A & 44 & $\begin{array}{l}\text { Abdullah Gül, Türk-Alman, Ankara } \\
\text { Sosyal Bilimler, Adana Bil.veTekn., Bursa } \\
\text { Teknik, İstanbul Medeniyet, Ardahan, } \\
\text { Şırnak, Hakkari, Erzurum Teknik, İzmir } \\
\text { Katip Çelebi, İYTE, Galatasaray, Gebze } \\
\text { Teknik, Bilecik, Nevşehir, Gümüşhane, } \\
\text { Recep Tayyip Erdoğan, Hitit, Amasya, } \\
\text { Ordu, Kırklareli, Mimar Sinan, Yıldırım } \\
\text { Beyazıt, Boğaziçi, Artvin Çoruh, Mardin } \\
\text { Artuklu, Sinop, Iğdır, Osmaniye Korkut } \\
\text { Ata, Siirt, Batman, Bitlis Eren, Bayburt, } \\
\text { Kilis } 7 \text { Aralık, Muş Alparslan, Tunceli, } \\
\text { Ağrı İbrahim Çeçen, Bartın, Çankırı } \\
\text { Karatekin, Yalova, Bingöl, Karamanoğlu } \\
\text { Mehmet Bey, Bozok }\end{array}$ & Total academic staff & 7981 & 1971 & 19132 \\
\hline Cluster B & 12 & $\begin{array}{l}\text { Gaziantep, Muğla Sıtkı Koçman, } \\
\text { Çanakkale } 18 \text { Mart, Trakya, Afyon } \\
\text { Kocatepe, Balıkesir, Adnan Menderes, } \\
\text { Celal Bayar, Dumlupınar, Mersin, } \\
\text { Mustafa Kemal, Namık Kemal }\end{array}$ & Total academic staff & 39480 & 28260 & 48908 \\
\hline Cluster C & 20 & $\begin{array}{l}\text { Dicle, Kırıkkale, Abant İzzet Baysal, } \\
\text { Yüzüncü Yıl, Necmettin Erbakan, Harran, } \\
\text { Niğde, Uşak, Aksaray, Kafkas, Ahi Evran, } \\
\text { Erzincan, Bülent Ecevit, Gaziosmanpaşa, } \\
\text { Sütçü İmam, Kastamonu, Mehmet Akif } \\
\text { Ersoy, Adıyaman, Düzce, Giresun }\end{array}$ & Total academic staff & 22882 & 16479 & 30439 \\
\hline Cluster D & 6 & $\begin{array}{l}\text { Atatürk, Dokuz Eylül, Gazi, Marmara, } \\
\text { Ankara, İstanbul }\end{array}$ & $\begin{array}{l}\text { Foundation year } \\
\text { Total students } \\
\text { Total academic staff }\end{array}$ & $\begin{array}{l}1963 \\
78606 \\
3656\end{array}$ & $\begin{array}{l}1933 \\
66487 \\
2642 \\
\end{array}$ & $\begin{array}{l}1982 \\
113568 \\
5130 \\
\end{array}$ \\
\hline Cluster E & 5 & $\begin{array}{l}\text { Akdeniz, Süleyman Demirel, Sakarya, } \\
\text { Selçuk, Kocaeli }\end{array}$ & $\begin{array}{l}\text { Foundation year } \\
\text { Total students } \\
\text { Total academic staff }\end{array}$ & $\begin{array}{l}1986 \\
71248 \\
2277\end{array}$ & $\begin{array}{l}1975 \\
57113 \\
1960 \\
\end{array}$ & $\begin{array}{l}1992 \\
80076 \\
2731 \\
\end{array}$ \\
\hline Cluster F & 6 & $\begin{array}{l}\text { Anadolu, Eskişehir Osmangazi, Yıldız } \\
\text { Teknik, İTÜ, ODTÜ, Hacettepe }\end{array}$ & $\begin{array}{l}\text { Foundation year } \\
\text { Total students } \\
\text { Total academic staff }\end{array}$ & $\begin{array}{l}1969 \\
33964 \\
2260\end{array}$ & $\begin{array}{l}1944 \\
27945 \\
1514 \\
\end{array}$ & $\begin{array}{l}1993 \\
43470 \\
3683\end{array}$ \\
\hline Cluster G & 11 & $\begin{array}{l}\text { Erciyes, KATÜ, Ege, Uludağ, Fırat, İnönü, } \\
\text { Karabük, Çukurova, Pamukkale, } \\
\text { Ondokuz Mayıs, Cumhuriyet }\end{array}$ & $\begin{array}{l}\text { Foundation year } \\
\text { Total students } \\
\text { Total academic staff }\end{array}$ & $\begin{array}{l}1975 \\
48316 \\
2088\end{array}$ & $\begin{array}{l}1955 \\
36212 \\
917\end{array}$ & $\begin{array}{l}2007 \\
61180 \\
3178\end{array}$ \\
\hline
\end{tabular}


Table 1 reveals that the clusters contain the following numbers of state universities: Cluster A (44 universities), Cluster B (12 universities), Cluster C (20 universities), Cluster D (6 universities), Cluster E (5 universities), Cluster F (6 universities), and Cluster G (11 universities).

The universities in Cluster A were founded after 2006, with the exception of Boğaziçi, Mimar Sinan Güzel Sanatlar, Galatasaray, Gebze Teknik, and İzmir Yüksek Teknoloji Enstitüsü (IYTE). Although these universities are older than from the rest of the universities in the cluster, they have not focused on growth. Boğaziçi, the oldest university in Cluster A, prefers to maintain a small size and focused teaching and research. Gebze Teknik and IYTE, founded at the beginning of the 1990s, are research-intensive universities; therefore, they are also small-scale institutions. Mimar Sinan is a fine arts specialty university. Galatasaray is the first public university in Turkey to be founded on the basis of an international agreement. The number of students at each university in Cluster A is about 8,000 on average, and academic staff members number about 450 . The universities in Cluster B were mainly founded at the beginning of the 1990s. Gaziantep and Trakya University are older than average, and Namik Kemal, founded in 2006, is the youngest in this cluster. The universities in Cluster B have about 40,000 students and 1,400 academic staff members on average. Universities in this cluster have finished their growth. Cluster $C$ has mainly two groups. One group consists of universities founded after 2006 with a larger size of vocational schools. The other group includes universities founded in 1992 with small-size vocational schools. Dicle and Yüzüncü Yıl are older universities, founded in the 1970s, but their student numbers have not increased much. On average, the universities in Cluster $C$ have about 23,000 students and 1,000 academic staff members. Cluster D contains the largest and oldest universities founded before the 1980s. The universities in this cluster have about 80,000 students and more than 3,500 academic staff on average. Cluster E consists of three universities that were founded in 1992 with large vocational schools. In this cluster, the other two universities Selçuk, founded in 1975, and Antalya, founded in 1982, are exceptions in terms of their foundation years. On average, the universities in Cluster E have more than 70,000 students and about 2,300 academic staff members. Cluster F contains the medium-sized and relatively oldest universities founded around and before the 1980s, with the exception of Eskişehir Osmangaz. The universities in Cluster F have about 34,000 students and more than 2,250 academic staff members on average. When we compare Cluster $\mathrm{E}$ and Cluster F, we can easily recognize that they have similar academic staff sizes, but the number of students is two times higher in Cluster E than in Cluster F. The universities in Cluster F are generally technical universities. Those in Cluster G were mainly founded before the 1980s in different regions of Turkey. In this cluster, Pamukkale, founded in 1992, and Karabük, founded in 2006, are two exceptions. Karabük seems to be the largest university among those that were founded after 2006. The universities in Cluster $G$ have about 50,000 students and more than 2,000 academic staff members on average.

The findings of this study showed that the foundation year is an important variable to classify universities in terms of institutional size, but it cannot be used as the only variable. For example, Tosun (2015,p. 88) reported that state universities could be categorized into six groups based on their foundation years: A (1933-1971), B (1973-1978), C (1982-1987), D (1992-1994), E (2006-2008), and F (2010-2011). When we compare the findings of our cluster analysis and the foundation year-based categorization of universities, it seems that the foundation year-based classification does not represent the current institutional sizes of the universities. We can argue that the classification of universities should be based on multi-variables for more valid and reliable classifications.

Lastly, it should be emphasized that vocational schools are one of the significant variables in the classification of universities in terms of institutional size. The size of a university's vocational school differentiates the cluster membership of the university. Among the universities founded after 2006, Karabük is the largest. In the cluster analyses without vocational schools, Necmettin Erbakan is the second in size among the universities founded after 2006. 
Table 2. Hierarchical Cluster Analysis of Foundation Universities According to Quantitative Variables

\begin{tabular}{|c|c|c|c|c|c|c|}
\hline Cluster & $\mathbf{n}$ & Universities & Variables & Mean & Min. & Max. \\
\hline \multirow{4}{*}{ Cluster A } & & $\begin{array}{l}\text { Alanya Hamdullah Emin Paşa, Murat } \\
\text { Hüdavendigar. Kanuni. Sanko, Selahaddin }\end{array}$ & Foundation year & 2010 & 1999 & 2014 \\
\hline & & $\begin{array}{l}\text { Eyyübi, Bursa Orhangazi, TED, İstanbul } \\
\text { MEF, İstanbul } 29 \text { Mayıs, Acıbadem, Toros, }\end{array}$ & Total students & 1559 & 0 & 6335 \\
\hline & & Canik Bașarı, Süleyman SSah, Nuh Naci & & & & \\
\hline & & $\begin{array}{l}\text { Yazgan, UA Antalya, Sabahattin Zaim, Ufuk, } \\
\text { Gedik, İstanbul Esenyurt, İstanbul Bilim, } \\
\text { Avrasya, Üsküdar }\end{array}$ & Total academic staff & 151 & 4 & 552 \\
\hline \multirow{3}{*}{ Cluster B } & \multirow{3}{*}{\multicolumn{2}{|c|}{3 Gelişim, İstanbul Arel, Nişantaşı }} & Foundation year & 2009 & 2007 & 2011 \\
\hline & & & Total students & 13334 & 11112 & 15497 \\
\hline & & & Total academic staff & 363 & 313 & 403 \\
\hline \multirow{3}{*}{ Cluster C } & & $\begin{array}{l}\text { Haliç, İzmir Ekonomi, Maltepe, Gediz, Yaşar, } \\
\text { Atılım, Çankaya, İstanbul Ticaret, Zirve, }\end{array}$ & Foundation year & 2003 & 1992 & 2011 \\
\hline & & $\begin{array}{l}\text { Doğuş, Işık, Yeni Yüzyıl, İstanbul Medipol, } \\
\text { Turgut Özal, Melikşah, Sabancı, Hasan }\end{array}$ & Total students & 5902 & 2834 & 9179 \\
\hline & & $\begin{array}{l}\text { Kalyoncu, İstanbul Kemerburgaz, Mevlana, } \\
\text { FSM, İstanbul Şehir, KTO Karatay, THK } \\
\text { Üniv. }\end{array}$ & Total academic staff & 306 & 138 & 632 \\
\hline \multirow{3}{*}{ Cluster D } & \multirow{3}{*}{4} & \multirow{3}{*}{ Başkent, İstanbul Kültür, Fatih, Bilkent } & Foundation year & 1993 & 1985 & 1997 \\
\hline & & & Total students & 12540 & 10285 & 15225 \\
\hline & & & Total academic staff & 821 & 358 & 1517 \\
\hline \multirow{3}{*}{ Cluster E } & \multirow{3}{*}{3} & \multirow{3}{*}{ Bahçeşehir, İstanbul Bilgi, Okan } & Foundation year & 1997 & 1996 & 1999 \\
\hline & & & Total students & 18696 & 17105 & 19994 \\
\hline & & & Total academic staff & 620 & 557 & 682 \\
\hline \multirow{3}{*}{ Cluster F } & \multirow{3}{*}{\multicolumn{2}{|c|}{2 Beykent, Yeditepe }} & Foundation year & - & 1996 & 1997 \\
\hline & & & Total students & 22178 & 22130 & 22226 \\
\hline & & & Total academic staff & 679 & 437 & 921 \\
\hline \multirow{3}{*}{ Cluster G } & \multirow{3}{*}{\multicolumn{2}{|c|}{1 İstanbul Aydın }} & Foundation year & 2007 & - & - \\
\hline & & & Total students & 32415 & - & - \\
\hline & & & Total academic staff & 653 & - & - \\
\hline
\end{tabular}

Table 2 reveals that Cluster A contains 27foundation universities that were founded after 2010. They are small in terms of institutional size. The number of students is about 1,500 and staff number about 150 on average. In Cluster B, there are three universities: Gelişim, İstanbul Arel, and Nişantaş1. İstanbul Arel was founded in 2007, Nişantaşı in 2009, and Gelişim in 2011. They have about 13,000 students and about 360 academic staff. They are among those universities that have a large number of vocational students. In cluster $\mathrm{C}$, there are 29 foundation universities that show heterogeneous characteristics. On average, there are about 6,000 students and 300 academic staff members. Cluster D consists of four universities: Başkent, İstanbul Kültür, Fatih, and Bilkent. These universities are medium sized and relatively long tenured. The number of students is about 12,500 and academic staff number about 800 or more, on average. Cluster $\mathrm{E}$ includes Bahçeşehir, İstanbul Bilgi, and Okan. They have more than 18,500 students and over 600 academic staff members, on average. When we compare Cluster D and Cluster E, it seems that those in Cluster E have more students than those in Cluster D, but their 
academic staff sizes are smaller. Cluster F consists of Beykent and Yeditepe. On average, they have more than 22,000 students and about 680 staff members. This cluster seems homogenous in terms of student numbers, but there is a large difference between the two universities in terms of academic staff size. The last cluster, G, has only one member. Although it was established within the last ten years, it is the largest foundation university in terms of institutional size, measured by student population and number of programs. However, it has 653 academic staff members, which is a medium size among foundation universities.* $^{*}$

Vocational schools are also a significant variable in the classification of foundation universities. The size of a university's vocational school differentiates the cluster membership of the university. İstanbul Aydın, Nişantaşı, Beykent, Gelişim, and İstanbul Arel have the largest numbers of vocational students, in that order. Each of these universities has more than 5,000 vocational students. For undergraduate students, the largest are, in order, Yeditepe, Beykent, İstanbul Aydın, İstanbul Bilgi, İ. D. Bilkent, and Bahçeşehir. Each of these universities has more than 10,000 undergraduate students. For graduate students, Okan, Bahçeşehir, İstanbul Bilgi, Yeditepe, Fatih, İstanbul Aydın, and Türk Hava Kurumu have the largest sizes. These universities have more than 3,000 students, who are mainly students in graduate studies without a thesis.

Results of Cluster Analysis by Ranking Scores

This section presents the results of cluster analyses on the basis of ranking scores. The results of state and foundation universities are given in Tables 3 and 4.

Table 3. Hierarchical Cluster Analysis of State Universities According to Ranking Scores

\begin{tabular}{|c|c|c|c|c|c|c|}
\hline Cluster & $\mathbf{n}$ & Universities & Variables & Mean & Min. & Max. \\
\hline \multirow{3}{*}{ Cluster A } & \multirow{3}{*}{11} & \multirow{3}{*}{$\begin{array}{l}\text { Dokuz Eylül, Süleyman Demirel, Akdeniz, } \\
\text { Fırat, Marmara, Yıldız Teknik, Çukurova, } \\
\text { Selçuk, Gaziantep, Atatürk, Erciyes }\end{array}$} & URAP_Türkiye & 61151 & 57085 & 64509 \\
\hline & & & Webometrics & 1187 & 981 & 1439 \\
\hline & & & TUBİTAK Index & 44,06 & 30,04 & 63,93 \\
\hline \multirow{3}{*}{ Cluster B } & \multirow{3}{*}{12} & \multirow{3}{*}{$\begin{array}{l}\text { Sütçü İmam, Pamukkale, Sakarya, Düzce, } \\
\text { Eskişehir Osmangazi, Uludağ, Karadeniz } \\
\text { Teknik, Kocaeli, İnönü, Mersin, Anadolu, } \\
\text { Gaziosmanpaşa }\end{array}$} & URAP_Türkiye & 52738 & 47597 & 56610 \\
\hline & & & Webometrics & 1827 & 755 & 5194 \\
\hline & & & TUBİTAK Index & 37,69 & 30,09 & 53,17 \\
\hline \multirow{3}{*}{ Cluster C } & \multirow{3}{*}{8} & \multirow{3}{*}{$\begin{array}{l}\text { Gazi, İYTE, Gebze Teknik, Ege, İstanbul } \\
\text { Teknik, İstanbul, Ankara, Boğaziçi }\end{array}$} & URAP_Türkiye & 71844 & 69333 & 74041 \\
\hline & & & Webometrics & 940 & 439 & 2277 \\
\hline & & & TUBİTAK Index & 58,31 & 38,40 & 79,66 \\
\hline \multirow{3}{*}{ Cluster D } & \multirow{3}{*}{2} & \multirow{3}{*}{ Hacettepe, ODTÜ } & URAP_Türkiye & 80882 & 80624 & 81140 \\
\hline & & & Webometrics & 634 & 490 & 778 \\
\hline & & & TUBİTAK Index & 70,17 & 54,37 & 85,96 \\
\hline
\end{tabular}

Table 3 reveals that Cluster A contains 10 universities that were founded at the beginning of the 1980s or earlier in main cities in different regions of Turkey. In this cluster, Süleyman Demirel, founded in 1992, is an exception. In Cluster B, there are 12 universities representing a combination of universities founded in the 1980s or earlier and universities founded at the beginning of the 1990s. In this cluster, Düzce, founded in 2006, is an exception. In Cluster C, there are 9 universities that are among the oldest universities, except IYTE and Gebze Teknik. The last two universities were founded as technology and research universities. Lastly, Cluster D contains Hacettepe and ODTÜ, which have the highest scores in the rankings. 
In the cluster analyses using ranking scores, state universities were divided into four clusters. When we compare the results of the cluster analyses on the basis of quantitative variables and ranking scores, we see that the cluster membership of the universities has changed. Gebze Teknik and IYTE are now in the cluster that contains newly founded and small-sized universities in terms of institutional size. In the ranking score cluster, they are in the group of the largest and oldest universities, along with Gazi, Ege, İTÜ, İstanbul, Ankara, and Boğaziçi. İTÜ and Boğaziçi also shifted to the cluster of the largest and oldest universities. It should be emphasized that Hacettepe and ODTÜ were clustered in the same group, changing from Cluster C. Among the universities founded after 2006, only Düzce is included in the clustering by rankings.

Table 4. Hierarchical Cluster Analysis of Foundation Universities According to Ranking Variables

\begin{tabular}{|c|c|c|c|c|c|c|}
\hline Cluster & $\mathbf{n}$ & Universities & Variables & Mean & Min. & Max. \\
\hline \multirow{3}{*}{ Cluster A } & \multirow{3}{*}{4} & \multirow{3}{*}{ Atılım, Çankaya, Özyeğin, Yeditepe } & URAP_Türkiye & 51798 & 50155 & 53487 \\
\hline & & & Webometrics & 1970 & 1418 & 2872 \\
\hline & & & TUBİTAK Index & 50,87 & 41,87 & 73,47 \\
\hline \multirow{3}{*}{ Cluster B } & \multirow{3}{*}{1} & \multirow{3}{*}{ Okan } & URAP_Türkiye & 22457 & - & - \\
\hline & & & Webometrics & 5293 & - & - \\
\hline & & & TUBİTAK Index & 33,67 & - & - \\
\hline \multirow{3}{*}{ Cluster C } & \multirow{3}{*}{3} & \multirow{3}{*}{ Bahçeşehir, İzmir Ekonomi, Kadir Has } & URAP_Türkiye & 37312 & 36721 & 37779 \\
\hline & & & Webometrics & 3165 & 2526 & 4268 \\
\hline & & & TUBİTAK Index & 34,63 & 33,98 & 35,75 \\
\hline \multirow{3}{*}{ Cluster D } & \multirow{3}{*}{2} & \multirow{3}{*}{ Fatih, TOBB } & URAP_Türkiye & 59593 & 59083 & 60102 \\
\hline & & & Webometrics & 1828 & 1654 & 2001 \\
\hline & & & TUBİTAK Index & 53,73 & 40,45 & 67 \\
\hline \multirow{3}{*}{ Cluster E } & \multirow{3}{*}{3} & \multirow{3}{*}{ İ.D. Bilkent, Koç, Sabancı } & URAP_Türkiye & 68856 & 66510 & 70561 \\
\hline & & & Webometrics & 950 & 686 & 1105 \\
\hline & & & TUBİTAK Index & 80,98 & 76,44 & 88,40 \\
\hline
\end{tabular}

Table 4 shows that Cluster A contains four foundation universities that were founded at the end of the 1990s, except Özyeğin, which was founded in 2007. In Cluster B, there is only one university, Okan. Cluster C includes three universities: Bahçeşehir, İzmir Ekonomi, and Kadir Has. Fatih and TOBB are in Cluster D. Lastly, Cluster E contains Bilkent, Koç, and Sabanci.

In the cluster analyses using ranking scores, the foundation universities were divided into five clusters. When we compare the results of the cluster analyses on the basis of quantitative variables and ranking scores for the foundation universities, we see that the cluster membership of the universities has changed. The results of the cluster analyses by rankings showed that Bilkent, Koç, and Sabancı were clustered in the same group, by differentiation from the universities that were in the same class in the cluster analyses based on quantitative variables.

\section{Results of Cluster Analysis by Teaching and Publication Performance}

This section presents the results of cluster analyses on the basis of teaching and publication performance. The results of state and foundation universities are given in Tables 5, 6, 7, and 8. 
Table 5. Hierarchical Cluster Analysis of State Universities According to Publication Performance

\begin{tabular}{|c|c|c|c|c|c|c|}
\hline Cluster & $\mathbf{n}$ & Universities & Variables & Mean & Min. & Max. \\
\hline Cluster A & 32 & $\begin{array}{l}\text { Bayburt, Şırnak, Bursa Teknik, Amasya, } \\
\text { Hakkari, Bilecik, Kastamonu, Çankırı } \\
\text { Karatekin, Yıldırım Beyazıt, Siirt, Batman, } \\
\text { Hitit, Bartın, Muğla Sıtkı Koçman, Ağrı } \\
\text { İbrahim Çeçen, Mehmet Akif Ersoy, } \\
\text { Anadolu, Sinop, Gümüşhane, Namık Kemal, } \\
\text { Muş Alparslan, Aksaray, Bingöl, Erzincan, } \\
\text { Tunceli, Adnan Menderes, İzmir Katip } \\
\text { Çelebi, Ahi Evran, Balıkesir, Sakarya, } \\
\text { Erzurum Teknik, Trakya }\end{array}$ & $\begin{array}{l}\text { Publication per } \\
\text { academic staff } \\
\text { member with a } \\
\text { Ph.D. }\end{array}$ & 0,37 & 0,30 & 0,45 \\
\hline Cluster B & 24 & $\begin{array}{l}\text { Kafkas, Mersin, İnönü, Celal Bayar, İstanbul } \\
\text { Medeniyet, Marmara, Sütçü İmam, } \\
\text { Çanakkale } 18 \text { Mart, } 9 \text { Eylül, Adıyaman, } \\
\text { Yüzüncü Yıl, Bozok, Kırıkkale, Niğde, } \\
\text { Cumhuriyet, Osmaniye Korkut Ata, } \\
\text { Dumlupınar, Recep Tayyip Erdoğan, } \\
\text { Pamukkale, Afyon Kocatepe, Abant İzzet } \\
\text { Baysal, Bitlis Eren, Bülent Ecevit, } \\
\text { Karamanoğlu Mehmet Bey }\end{array}$ & $\begin{array}{l}\text { Publication per } \\
\text { academic staff } \\
\text { member with a } \\
\text { Ph.D. }\end{array}$ & 0,52 & 0,47 & 0,57 \\
\hline Cluster C & 18 & $\begin{array}{l}\text { Ankara Sosyal Bilimler, Türk-Alman, Mardin } \\
\text { Artuklu, Adana Bilim ve Teknik, Ardahan, } \\
\text { Necmettin Erbakan, Uşak, Mimar Sinan, } \\
\text { Giresun, Kırklareli, Artvin Çoruh, Iğdır, } \\
\text { Yalova, Karabük, Ordu, Abdullah Gül, } \\
\text { Galatasaray, Kilis } 7 \text { Aralık }\end{array}$ & $\begin{array}{l}\text { Publication per } \\
\text { academic staff } \\
\text { member with a } \\
\text { Ph.D. }\end{array}$ & 0,20 & 0 & 0,29 \\
\hline Cluster D & 24 & $\begin{array}{l}\text { Ege, Selçuk, Ankara, Nevşehir, Erciyes, Gazi, } \\
\text { Gaziantep, Çukurova, Gaziosmanpaşa, } \\
\text { İstanbul, Kocaeli, Mustafa Kemal, Düzce, } \\
\text { Dicle, Uludă̆, Atatürk, } 19 \text { Mayıs, Süleyman } \\
\text { Demirel, Harran, Akdeniz, KATÜ, Eskişehir } \\
\text { Osmangazi, Fırat, Yıldız Teknik }\end{array}$ & $\begin{array}{l}\text { Publication per } \\
\text { academic staff } \\
\text { member with a } \\
\text { Ph.D. }\end{array}$ & 0,70 & 0,61 & 0,89 \\
\hline Cluster E & 2 & Gebze Teknik, ODTÜ & $\begin{array}{l}\text { Publication per } \\
\text { academic staff } \\
\text { member with a } \\
\text { Ph.D. }\end{array}$ & 1,60 & 1,53 & 1,66 \\
\hline Cluster F & 4 & Boğaziçi, İYTE, Hacettepe, İstanbul Teknik & $\begin{array}{l}\text { Publication per } \\
\text { academic staff } \\
\text { member with a } \\
\text { Ph.D. }\end{array}$ & 1,16 & 1 & 1,29 \\
\hline
\end{tabular}

Table 5 reveals that the state universities were classified into six clusters. The universities in Cluster A, which has 32 members, were founded after 2006, with the exception of Muğla Sitkı Koçman, Balıkesir, and Sakarya. In this group, the number of publications per academic staff member with a Ph.D. is one of the lowest among the clusters, with a value of 0.37 . Cluster B consists of 24 universities. The universities in this group were founded largely in 1992. There are some members of this cluster founded after 2006. In Cluster B, the mean of number of publications per academic staff member with a Ph.D. is 0.52, which is higher than Cluster A but below the overall average. Cluster C contains newer universities founded after 2006, with the exception of Mimar Sinan Güzel Sanatlar and Galatasaray. The average number of publications per academic staff member with a Ph.D. in this cluster is 0.20 , which is 
the lowest among the clusters. The placements of Mimar Sinan Güzel Sanatlar and Galatasaray are not easy to explain. Their focus of education may be a reason for their classification level; still, this level seems very low for the capacity of the two universities. Cluster D includes those 24 universities that were founded in 1992, 1982, and before 1982. This cluster seems representative of the average performance in terms of publications, with a value of 0.70 . We noted that two members of this cluster, Nevşehir and Düzce, are newer ones that were founded after 2006. Cluster E contains Gebze Teknik and ODTÜ, which are the highest ranked in terms of publication performance. The average value of this cluster is 1.60. Cluster F, with an average value of 1.16, has the members that are in the second highest group in terms of the number of publications per academic staff member with a Ph.D.

Table 6. Hierarchical Cluster Analysis of Foundation Universities According to Publication Performance

\begin{tabular}{|c|c|c|c|c|c|c|}
\hline Cluster & $\mathbf{n}$ & Universities & Variables & Mea & Min. & Max \\
\hline Cluster A & 40 & $\begin{array}{l}\text { Murat Hüdavendigar, Selahaddin } \\
\text { Eyyübi, Alanya Hamdullah Emin, THK, } \\
\text { Biruni, FSM, Bursa Orhangazi, } \\
\text { Sabahattin Zaim, İstanbul MEF, Sanko, } \\
\text { İstanbul } 29 \text { Mayıs, Gelişim, KTO } \\
\text { Karatay, İstanbul Esenyurt, Nişantaşı, } \\
\text { Melikşah, Turgut Özal, İstanbul Bilgi, } \\
\text { Okan, İstanbul Şehir, Mevlana, İstanbul } \\
\text { Ticaret, İstanbul Medipol, Kanuni, İpek, } \\
\text { Yeni Yüzyıl, Hasan Kalyoncu, Gedik, } \\
\text { Avrasya, Gediz, Haliç, Beykent, Şifa, } \\
\text { İstanbul Aydın, İstanbul Kemerburgaz, } \\
\text { İstanbul Arel, Üsküdar, Süleyman Şah, } \\
\text { Toros, Nuh Naci Yazgan }\end{array}$ & $\begin{array}{l}\text { Publications per } \\
\text { academic staff } \\
\text { member with a Ph.D. }\end{array}$ & 0,10 & 0 & 0,26 \\
\hline Cluster B & 6 & $\begin{array}{l}\text { Çă̆, İstanbul Bilim, Acrbadem, Yeditepe, } \\
\text { İzmir Ekonomi, Özyeğin }\end{array}$ & $\begin{array}{l}\text { Publications per } \\
\text { academic staff } \\
\text { member with a Ph.D. }\end{array}$ & 0,67 & 0,61 & 0,77 \\
\hline Cluster C & 13 & $\begin{array}{l}\text { Bahçeşehir, Ufuk, Işık, Kadir Has, Canik } \\
\text { Başarı, TED, İstanbul Kültür, Piri Reis, } \\
\text { Zirve, İzmir, UA Antalya, Maltepe, Yaşar }\end{array}$ & $\begin{array}{l}\text { Publications per } \\
\text { academic staff } \\
\text { member with a Ph.D. }\end{array}$ & 0,36 & 0,28 & 0,52 \\
\hline Cluster D & 3 & Doğuş, İ.D.Bilkent, Sabancı & $\begin{array}{l}\text { Publications per } \\
\text { academic staff } \\
\text { member with a Ph.D. }\end{array}$ & 1,65 & 1,54 & 1,78 \\
\hline Cluster E & 7 & $\begin{array}{l}\text { Çankaya, Fatih, Başkent, Atılım, Bezm-i } \\
\text { Alem, TOBB, Koç }\end{array}$ & $\begin{array}{l}\text { Publications per } \\
\text { academic staff } \\
\text { member with a Ph.D. }\end{array}$ & 1,08 & 0,88 & 1,37 \\
\hline
\end{tabular}

Table 6 shows that the foundation universities were classified in five clusters. Cluster A consists of 40 foundation universities with the lowest publication performance. Most of the members of this cluster are newly founded foundation universities. In this cluster, there are also foundation universities that are teaching-focused with a relatively longer tenure. Cluster B contains six foundation universities with an average publication performance value of 0.67 . Cluster $C$ includes universities that are teachingfocused with a relatively longer tenure. In this cluster, the average number of publications per academic staff member with a Ph.D. is higher than Cluster B. In Cluster D, Doğuş, İ. D. Bilkent, and Sabancı are three foundation universities with the highest publication performance, 1.65. Cluster $\mathrm{E}$ consists of seven foundation universities with the second highest publication performance. The average of this group is 1.08 . 
Table 7. Hierarchical Cluster Analysis of State Universities According to Teaching Performance

\begin{tabular}{|c|c|c|c|c|c|c|}
\hline Cluster & $\mathbf{n}$ & Universities & Variables & Mean & Min. & Max. \\
\hline Cluster A & & $\begin{array}{l}\text { Çanakkale } 18 \text { Mart, Uludağ, Ahi Evran, } \\
\text { Niğde, Batman, Iğdır, Trakya, Mustafa } \\
\text { Kemal, Namık Kemal, Tunceli, Bartın, } \\
\text { Gaziantep, Hitit, Celal Bayar, Sütçü } \\
\text { İmam, Şırnak, Afyon Kocatepe, Hakkari, } \\
\text { Süleyman Demirel, Yalova, Bingöl, } \\
\text { Selçuk, Kilis } 7 \text { Aralık, Gümüşhane, Siirt, } \\
\text { Mehmet Akif Ersoy }\end{array}$ & $\begin{array}{l}\text { Students per } \\
\text { academic staff } \\
\text { member with a } \\
\text { Ph.D. }\end{array}$ & 64,6 & 57,1 & 74,8 \\
\hline Cluster B & 26 & $\begin{array}{l}\text { Harran, } 19 \text { Mayıs, Artvin Çoruh, Çankırı } \\
\text { Karatekin, Marmara, Adıyaman, İnönü, } \\
\text { Erciyes, Bozok, Çukurova, Atatürk, } \\
\text { Düzce, Akdeniz, Ordu, Aksaray, } \\
\text { Erzincan, Ardahan, Bülent Ecevit, } \\
\text { Cumhuriyet, Gaziosmanpaşa, } \\
\text { Pamukkale, Muğla Sıtkı Koçman, } \\
\text { KATÜ, Kırıkkale, Adnan Menderes, } \\
\text { Mersin }\end{array}$ & $\begin{array}{l}\text { Students per } \\
\text { academic staff } \\
\text { member with a } \\
\text { Ph.D. }\end{array}$ & 51,1 & 46,2 & 55,8 \\
\hline Cluster C & & Kırklareli, Muş Alparslan, Nevşehir & $\begin{array}{l}\text { Students per } \\
\text { academic staff } \\
\text { member with a } \\
\text { Ph.D. }\end{array}$ & 113,8 & 106,9 & 124 \\
\hline Cluster D & 15 & $\begin{array}{l}\text { Karabük, Karamanoğlu Mehmet Bey, } \\
\text { Dumlupınar, Ağrı İbrahim Çeçen, Bitlis } \\
\text { Eren, Osmaniye Korkut Ata, Amasya, } \\
\text { Bilecik, Kastamonu, Bayburt, Kocaeli, } \\
\text { Sakarya, Giresun, Uşak, Balıkesir }\end{array}$ & $\begin{array}{l}\text { Students per } \\
\text { academic staff } \\
\text { member with a } \\
\text { Ph.D. }\end{array}$ & 85 & 77 & 1000 \\
\hline Cluster E & 22 & $\begin{array}{l}\text { Ege, Sinop, Ankara, Dicle, Necmettin } \\
\text { Erbakan, Anadolu, Boğaziçi, Gebze } \\
\text { Teknik, İTÜ, ODTÜ, Yüzüncü Yıl, Gazi, } \\
\text { Yıldız Teknik, Eskişehir Osman Gazi, } \\
\text { Abant İzzet Baysal, İstanbul, Erzurum } \\
\text { Teknik, Mardin Artuklu, Dokuz Eylül, } \\
\text { Kafkas, Fırat, Recep Tayyip Erdoğan }\end{array}$ & $\begin{array}{l}\text { Students per } \\
\text { academic staff } \\
\text { member with a } \\
\text { Ph.D. }\end{array}$ & 36,9 & 30,9 & 43,5 \\
\hline Cluster F & 12 & $\begin{array}{l}\text { İYTE, Mimar Sinan, Yıldırım Beyazıt, } \\
\text { Galatasaray, Hacettepe, Adana Bilim, } \\
\text { Türk-Alman, Bursa Teknik, İstanbul } \\
\text { Medeniyet, İzmir Katip Çelebi, } \\
\text { Abdullah Gül, Ankara Sosyal Bilimler }\end{array}$ & $\begin{array}{l}\text { Students per } \\
\text { academic staff } \\
\text { member with a } \\
\text { Ph.D. }\end{array}$ & 15,25 & 0 & 27,13 \\
\hline
\end{tabular}

Table 7 shows that state universities were classified in six clusters according to teaching quality. The universities in Cluster A, which has 26 members, were founded in 1982, 1992, or 2006. In this group, the number of students per academic staff member with a Ph.D. is 64.6. Cluster B consists of 26 universities that have similar members. The difference between Cluster A and Cluster B is that Cluster $B$ has relatively better teaching quality with a value of 51.1. Cluster $C$ consists of three universities with the highest number of students per academic staff member with a Ph.D. The value of teaching performance is 113.8. Cluster D includes those 15 universities that were largely founded after 2006, with the exception of Dumlupınar, Kocaeli, Sakarya, and Balıkesir. These four universities were founded in 1992 with many vocational students. The average of this cluster is 85 students per academic staff 
member with a Ph.D. Cluster E contains three subgroups that were founded in or before 1982, or are newly founded universities. When we regard newly founded universities as an exception, the universities in this cluster have better educational quality, with an average value of 36.9. Lastly, Cluster F consists of medium-sized and long-tenured universities. This group has the highest value: 15.25 students per academic staff member with a Ph.D.

Table 8. Hierarchical Cluster Analysis of Foundation Universities According to Teaching Performance

\begin{tabular}{|c|c|c|c|c|c|}
\hline Cluster $\mathbf{n}$ & Universities & Variables & Mean & Min. & Max. \\
\hline Cluster A 21 & $\begin{array}{l}\text { İpek, İstanbul MEF, Şifa, Bezm-i Alem, } \\
\text { Acıbadem, Selahaddin Eyyübi, Alanya } \\
\text { Hamdullah Emin Paşa, Sanko, Murat } \\
\text { Hüdavendigar, Kanuni, İstanbul } \\
\text { Kemerburgaz, Sabahattin Zaim, TED, Ufuk, } \\
\text { Başkent, Biruni, İstanbul Medipol, İstanbul } \\
\text { Bilim, Koç, Bursa Orhangazi, İstanbul } 29 \\
\text { Mayıs }\end{array}$ & $\begin{array}{l}\text { Students per } \\
\text { academic staff } \\
\text { member with a } \\
\text { Ph.D. }\end{array}$ & 13 & 0 & 24,35 \\
\hline Cluster B 17 & $\begin{array}{l}\text { İzmir, Sabancı, TOBB, Turgut Özal, KTO } \\
\text { Karatay, Maltepe, Mevlana, Atılım, } \\
\text { Özyeğin, Yeni Yüzyıl, UA Antalya, } \\
\text { Yeditepe, Nuh Naci Yazgan, Süleyman Şah, } \\
\text { Canik Başarı, İ.D. Bilkent, İstanbul Esenyurt }\end{array}$ & $\begin{array}{l}\text { Students per } \\
\text { academic staff } \\
\text { member with a } \\
\text { Ph.D. }\end{array}$ & 34,67 & 27,34 & 50,46 \\
\hline Cluster C 22 & $\begin{array}{l}\text { Avrasya, Doğuş, Bahçeşehir, İstanbul } \\
\text { Kültür, Gedik, Melikşah, Piri Reis, FSM, } \\
\text { Okan, Toros, Işık, İstanbul Ticaret, Çankaya, } \\
\text { Zirve, İzmir Ekonomi, Kadir Has, Haliç, } \\
\text { Fatih, İstanbul Şehir, Üsküdar, Hasan } \\
\text { Kalyoncu, Yaşar }\end{array}$ & $\begin{array}{l}\text { Students per } \\
\text { academic staff } \\
\text { member with a } \\
\text { Ph.D. }\end{array}$ & 48,13 & 35,6 & 59,62 \\
\hline Cluster D 5 & $\begin{array}{l}\text { Gediz, Gelişim, İstanbul Bilgi, Nişantaşı, } \\
\text { İstanbul Arel }\end{array}$ & $\begin{array}{l}\text { Students per } \\
\text { academic staff } \\
\text { member with a } \\
\text { Ph.D. }\end{array}$ & 72,53 & 67,04 & 83,32 \\
\hline Cluster E 4 & Beykent, İstanbul Aydın, THK, Çağ & $\begin{array}{l}\text { Students per } \\
\text { academic staff } \\
\text { member with a } \\
\text { Ph.D. }\end{array}$ & 110,84 & 98,79 & 129,54 \\
\hline
\end{tabular}

Table 8 shows that the foundation universities were classified in five clusters for teaching quality. Cluster A consists of 21 foundation universities with the highest teaching quality. Most of the members of this cluster are newly founded foundation universities, with the exception of Koç, Başkent, and Ufuk. On average, there were 397 students per academic staff member with a Ph.D. Cluster B contains 17 foundation universities, with an average of 48.13 students per academic staff member with a Ph.D. Cluster $C$ includes universities that can be divided into two groups. One group is teachingfocused, and the other consists of newer foundation universities. The average number of students per academic staff member with a Ph.D. is 48.13. In Cluster D, there are universities that are teachingfocused and also have large numbers of vocational students. There is an average of 72.53 students per academic staff member with a Ph.D. Lastly, Cluster E consists of sevenfoundation universities. The average number of students per academic staff member with a Ph.D. in this group is 110.84 . 


\section{Discussion and Conclusion}

In this study, universities in Turkey were classified by using hierarchical cluster analysis, which is a data-based classification. As Shin (2009) mentioned, this approach differs from conventional mission classification that uses predetermined criteria. A number of significant points emerged from the cluster analysis of the Turkish universities. The results of the cluster analysis showed that clustering universities by using institutional size and performance as two separate variables provided better results. Regarding legal status, state and foundation universities should be included in the cluster analysis for both variables, institutional size and performance. With a few exceptions, the size and tenure of foundation universities are smaller than state universities. Universities founded in the same years were divided into two clusters mainly according to the size of their vocational schools. The scale and tenure of universities differentiated them in terms of institutional size and performance variables. Old tenured universities in three big cities such as İstanbul, Gazi, and Ege, called classic universities in Üsdiken et al. (2013), are among the largest in size and have better publication performance than the average of Turkish universities. Atatürk, Kocaeli, Selçuk, Süleyman Demirel, Sakarya, and Akdeniz are among the largest in size, have a high percentage of vocational students, and show average publication performance. It was also found that when publication performance was compared, those universities that were small and medium sized, focused, and long tenured were separate from other universities. For both undergraduate and graduate level students, the numbers showed the highest percentage in those state universities that were founded before 1982. The percentage of vocational students is higher in state universities that were founded in 1992. Among foundation universities, Beykent, Yeditepe, and İstanbul Aydın are the largest in size. The results showed that in the analysis of universities, capacity and performance analysis should be conducted for better generalizations and policy development in practice.

In the results of the cluster analysis based on rankings and publication performance, Boğaziçi, Hacettepe, İTÜ, ODTÜ, Gebze Teknik, and IYTE were separated from other state universities. The results of the same analysis for foundation universities indicated that I.D. Bilkent, Koç, and Sabanc1 were separated from the rest of the foundation universities. General characteristics of the high performers in publication are long tenure, small or medium size but lower number of students per academic staff member with a Ph.D., and focused undergraduate and graduate studies.

This is an exploratory study to classify universities in Turkey according to institutional size and performance. Although Turkish universities were classified on the basis of empirical data, policy makers and researchers should be careful when using the results and take the institutional contexts of the universities into account. Each university has strong and weak programs, and the results may represent some fields more than others. It was found that there were some universities such as Gebze Teknik and IYTE that are relatively long tenured and small in size but have higher publication performance. On the other hand, some universities such as Galatasaray and Mimar Sinan Güzel Sanatlar are long tenured and small in size but have low publication performance. These findings showed us that in interpreting the results, one should consider the institutional contexts of the universities, compare clusters, and consider more than one variable to determine the position of a university. As McCormick and Zhao (2005) emphasized, the value of a classification is closely linked to its intended use rather than an absolute standard for the best classification.

There are some implications of this study for the field of higher education. It is obvious that there has been a significant quantitative growth in the higher education field in Turkey. There are also ongoing strategy, structure, and policy changes in Turkish higher education. Regarding the needs of Turkish higher education, we should conduct more than one cluster analysis of universities on the basis of purpose. Possible subjects for clustering include efficient resource allocation, fundraising, research and publication priority, educational investments, informing the public and stakeholders, and self and external evaluations of institutions. These subjects represent policy development areas for institutions as well as research topics for researchers. Another issue for cluster analysis may be focusing on the subdimensions (research, education, institution, services, etc.) of the higher education system. Before 
cluster analysis, researchers need reliable datasets and valid measurements. Valid measurement methodology is the responsibility of the researcher, and for reliable datasets, the support, collaboration, and coordination of institutions in the higher education system and other related organizations are necessary. Clustering or measuring universities' performances requires definitions of appropriate variables that are suitatable to measure the quality and effectiveness of universities. A multivariate analysis should be applied to measure several components of higher education institutions, such as education, research, services, and institutional variables. As Avkiran (2001) suggested, an evaluation of universities on the basis of quantifiable data should take into account that universities still retain certain key characteristics that differentiate them from other types of organizations.

\section{Limitations of the study}

In classifying and measuring the performance of universities, finding reliable data is a difficulty faced around the world. This study on clustering universities in Turkey also has some limitations. One of the main limitations is the lack of availability of data on institutional performance. Finding data on the size of universities seems relatively easy, but collecting performance-related data is very difficult. This study used data from universities that were founded after the 2010s. However, data on foundation years may not reflect the capacity and performance of new universities. A second limitation of the study is the use of publications in the Web of Science in the cluster analysis. Some of these very valuable publications, such as books, book chapters, and articles that are not cited in Web of Science (SCI, SSCI, and $\mathrm{AHCI}$ ) listed journals, were not used in the cluster analysis. Another limitation is the use of data on ranking scores (URAP, TUBITAK, and Webometrics), in which not all universities are included. More importantly, intangible assets and products that constitute institutional identities could not possibly be incorporated into an empirically based classification system. 


\section{References}

Avkiran, N. K. (2001). Investigating technical and scale efficiencies of Australian universities through data envelopment analysis. Socio-Economic Planning Sciences, 35(1), 57-80

Bartelse, J., \& Vught, F. (2007). Institutional profiles: Towards a typology of higher education institutions in Europe. IAU Horizons, 13(2-3), 9-11.

Carey, K. (2006). College rankings reformed: The case for a new order in higher education. Retrieved from Education Sector website: http://educationpolicy.air.org/sites/default/files/publications/CollegeRankingsReformed.pdf

Chu Ng, Y., \& Li, S. K. (2000). Measuring the research performance of Chinese higher education institutions: an application of data envelopment analysis. Education Economics, 8(2), 139-156.

Günay, D., \& Günay, A. (2011). 1933'den günümüz Türk yükseköğretiminde niceliksel gelişmeler. Yükseköğretim ve Bilim Dergisi, 1(1), 1-22.

Hair, J. F. Jr., Anderson, R. E., Tatham, R. L., \& Black, W. C. (1998). Multivariate data analysis (5th ed.). Upper Saddle River, NJ: Prentice Hall.

Harvey, L. (2008). Rankings of higher education institutions: A critical review. Quality in Higher Education, 14(3), 187-207.

Ibáñez, A., Larrañaga, P., \& Bielza, C. (2013). Cluster methods for assessing research performance: exploring Spanish computer science. Scientometrics, 97(3), 571-600.

Ioannidis, J. P., Patsopoulos, N. A., Kavvoura, F. K., Tatsioni, A., Evangelou, E., Kouri, I., \& Liberopoulos, G. (2007). International ranking systems for universities and institutions: A critical appraisal. Bmc Medicine, 5(1), 30.

Küçükcan, T., \& Gür, B. S. (2009). Tü̈kiye'de yuikseköğretim: Karşılaştırmalı bir analiz. Ankara: SETA Yayınları.

McCormick, A. C. (2008). The complex interplay between classification and ranking of colleges and universities: should the Berlin Principles apply equally to classification?. Higher Education in Europe, 33(2-3), 209-218.

McCormick, A. C., \& Zhao, C. M. (2005). Rethinking and reframing the Carnegie classification. Change: The Magazine of Higher Learning, 37(5), 51-57.

Marginson, S., \& Van der Wende, M. (2007). To rank or to be ranked: The impact of global rankings in higher education. Journal of Studies in International Education, 11(3-4), 306-329.

OECD. (2006). Education policy analysis: Focus on higher education 2005-2006. Retrieved from http://www.oecd.org/edu/skills-beyond-school/educationpolicyanalysisfocusonhighereducation-2005-2006edition.htm

Özoğlu, M., Gür, B. S., \& Gümüş, S. (2016). Rapid expansion of higher education in Turkey: The challenges of recently established public universities (2006-2013). Higher Education Policy, 29, 21-39.

Raponi, V., Martella, F., \& Maruotti, A. (2016). A biclustering approach to university performances: An Italian case study. Journal of Applied Statistics, 43(1), 31-45.

Shin, J. C. (2009). Classifying higher education institutions in Korea: A performance-based approach. Higher Education, 57(2), 247-266.

Stella, A., \& Woodhouse, D. (2007). Benchmarking in Australian higher education: A thematic analysis of $A U Q A$ audit reports. Melbourne, VIC: Australian Universities Quality Agency.

Thakur, M. (2007). The impact of ranking systems on higher education and its stakeholders. Journal of Institutional Research, 13(1), 83-96.

Tosun, H. (2015). Devlet üniversiteleri: Performans değerlendirme finansman modeli ve yeniden yapılanma. Ankara: Uzman Matbaacilik. 
TUBITAK. (2015). Ranking of The Entrepreneurial and Innovative University Index. Retrieved from https://www.tubitak.gov.tr/en/news/the-entrepreneurial-and-innovative-university-index-2015

URAP. (2015). University Ranking by Academic Performance (URAP). Retrieved from http://tr.urapcenter.org/2015/

Üsdiken, B., Topaler, B., \& Koçak, Ö. (2013). Yasa, piyasa ve örgüt tiplerinde çeşitlilik: 1981 sonrasında Türkiye' de üniversiteler. Ankara Üniversitesi SBF Dergisi, 68(03), 191-227.

Valadkhani, A., \& Ville, S. (2009). Discipline-specific forecasting of research output in Australian universities. Applied Economics Letters, 16(18), 1875-1880.

Valadkhani, A., \& Worthington, A. (2006). Ranking and clustering Australian university research performance, 1998-2002. Journal of Higher Education Policy and Management, 28(2), 189-210.

Van Dyke, N. (2005). Twenty years of university reports cards. Higher Education in Europe, 30(2), 103124.

Ward, J. H. J. (1963). Hierarchical grouping to optimize an objective function. Journal of the American Statistical Association, 58, 236-44.

YÖK. (2015a). Higher Education System in Turkey. Retrieved November 15, 2015, from http://www.yok.gov.tr/en/web/uluslararasi-iliskiler/turkiye-de-yuksekogretim-sistemi

YÖK. (2015b). Yayınlarımız. Retrieved November 15, 2015, from http://www.yok.gov.tr/web/guest/yayinlarimiz 